\title{
PENGARUH KEMAMPUAN KOSAKATA DAN STRUKTUR KALIMAT TERHADAP KEMAMPUAN MENULIS PARAGRAF DESKRIPSI SISWA SMA
}

\author{
Munirah, \& Hardian \\ Universitas Muhammadiyah Makassar \\ E-mail: munirah.fkip@gmail.com
}

\begin{abstract}
The research aims to determine: (1) the ability to use vocabulary and sentence structure class $\mathrm{X}$ SMA Negeri 2 Bantaeng District Bantaeng, (2) the ability to write a paragrafh description Bantaeng, and (3) the effect of the ability to use vocabulary and sentence structure to the ability to write a paragrafh description class X SMA Negeri 2 Bantaeng District Bantaeng. The research data such as the results of tests of vocabulary and sentence structure in the form of written tests of vocabulary and sentence structure of each of 50 numbers and descriptions essay writing test. The data source is a class XI student of SMAN 2 Bantaeng District Bantaeng. Data were analyzed using multiple linear regression analysis. The results showed that (1) the ability to use the vocabulary class X SMA Negeri 2 Bantaeng District Bantaeng and average value is 38.27, while the ability to use sentence structure average rating: 37.86. (2) The ability to write essays description of the class X SMA Negeri 2 Bantaeng District Bantaeng average value is 38.92 and (3) no effect between the ability to use vocabulary and sentence structure to the ability to write a paragrafh description of the class X SMA Negeri 2 Bantaeng District Bantaeng.
\end{abstract}

Keywords: vocabulary ability, sentence structure, andthe ability to writea paragrafhdescription

\begin{abstract}
Abstrak
Penelitian bertujuan untuk: (1) Mengkaji kemampuan menggunakan kosakata dan struktur kalimat siswa kelas X SMA Negeri 2 Bantaeng Kabupaten Bantaeng, (2) Mengetahui kemampuan menulis paragraf deskripsi Bantaeng, dan (3) mengetahui pengaruh kemampuan menggunakan kosakata dan struktur kalimat terhadap kemampuan menulis paragraf deskripsi siswa kelas X SMA Negeri 2 Bantaeng Kabupaten Bantaeng. Data penelitian berupa hasil tes kosakata dan struktur kalimat dalam bentuk tes menulis kosakata dan struktur kalimat masing-masing sebanyak 50 nomor dan tes menulis karangan deskripsi. Sumber data penelitian ini yaitu siswa kelas X.I SMA Negeri 2 Bantaeng Kabupaten Bantaeng. Data yang diperoleh dianalisis dengan menggunakan analisis regresi linear berganda. Hasil penelitian ini menunjukkan bahwa (1) Kemampuan menggunakan kosakata siswa kelas X SMA Negeri 2 Bantaeng Kabupaten Bantaeng dan nilai rata-ratanya yaitu 38,27, sedangkan kemampuan menggunakan struktur kalimat nilai rata-ratanya:37,86. (2) Kemampuan menulis karangan deksripsi siswa kelas X SMA Negeri 2 Bantaeng Kabupaten Bantaeng nilai rata-ratanya yaitu 38,92 dan (3) terdapat pengaruh antara kemampuan menggunakan kosakata dan struktur kalimat terhadap kemampuan menulis paragraf deskripsi siswa kelas X SMA Negeri 2 Bantaeng Kabupaten Bantaeng.
\end{abstract}

Kata kunci : kemampuan kosakata, struktur kalimat, dan kemampuan menulis paragraf deskripsi 


\section{PENDAHULUAN}

Bahasa adalah alat komunikasi yang digunakan manusia dengan sesama anggota masyarakat lain pemakai bahasa itu. Bahasa berisi gagasan, ide, pikiran, keinginan, atau perasaan yang ada pada diri si pembicara. Agar apa yang dipikirkan, diinginkan, atau dirasakan dapat diterima oleh pembicara atau orang yang diajak bicara, hendaklah bahasa yang digunakan dapat mendukung maksud atau pikiran dan perasaan pembicara dengan jelas. Oleh karena itu, belajar bahasa mengandalkan berpikir, fungsi otak akan bekerja sebagaimana belajar. Bahasa merupakan dasar fundamental berpikir.Bahasa juga dapat memperluas pikiran.Otak mempunyai kapasitas untuk menampung rangsangan-rangsangan yang masuk. Melalui bahasa manusia dapat mengekspresikan pikiran dan perasaannya baik secara lisan maupun tertulis. Keraf (2009: 16) "Bahasa adalah sistem lambang bunyi yang arbitrer yang digunakan oleh para anggota kelompok sosial untuk bekerjasama, berkomunikasi, dan mengidentifikasikan diri".

Pembelajaran bahasa Indonesia merupakan mata pelajaran wajib di lingkungan pendidikan formal. Hal itu, disebabkan oleh kedudukan dan fungsi bahasa Indonesia sebagai bahasa pengantar dalam dunia pendidikan. Pembelajaran bahasa Indonesia bertujuan membantu peserta didik mengembangkan kemampuan mengkomunikasikan berbagai konsep, baik secara lisan maupun secara tertulis.

Kemampuan berkomunikasi yang mendasar adalah kemampuan mengungkapkan makna dan pesan termasuk kemampuan menafsirkan, menilai, dan mengekspresikan diri dengan bahasa. Dalam pendidikan Nasional dirumuskan tujuan pembelajaran bahasa Indonesia, yaitu menjadikan anak didik sebagai manusia yang memiliki kepercayaan akan dasar dan filsafat negara serta kebanggaan terhadap bahasa dan sastra nasionalnya. Selain itu, memberikan anak didik penguasaan atas pemakaian bahasa Indonesia (Halim, 2005: 7).
Halim (2005: 7) menambahkan bahwa prioritas utama pengajaran bahasa Indonesia ditujukan pada sekolah dasar dan menengah karena merupakan penentu pendidikan selanjutnya. Pembelajaran bahasa Indonesia pada sekolah menengah memerlukan perhatian khusus. Dalam pengajaran bahasa, lingkungan kebahasaan yang diciptakan diarahkan untuk meningkatkan kualitas perilaku berbahasa. Oleh karena itu, sekolah dijadikan sebagai salah satu sarana yang sangat strategis dalam memberikan pembinaan dan pengajaran berbahasa kepada siswa. Pengajaran berbahasa Indonesia di sekolah-sekolah, khususnya di sekolah dasar harus dapat meletakkan dasar kemampuan berbahasa Indonesia yang baik dan benar.

Tarigan (2011: 14) mengatakan bahwa kualitas keterampilan berbahasa seseorangjelas bergantung kepada kualitas kosakata yang dimilikinya. Perkembangan kosakata mengandung pengertian lebih dari penambahan kata-kata baru ke dalam perbendaharaan pengalaman siswa. Perkembangan kosakata berarti menempatkan konsep-konsep baru dalam tatanan yang lebih baik atau ke dalam urutan-urutan atau susunan-susunan tambahan. Berdasarkan uraian tersebut dapat dinyatakan bahwa penguasaan kosakata dan struktur kalimat adalah bagian yang sangat penting dalam dunia pendidikan bahasa. Penguasaan kosakata dan struktur kalimat merupakan suatu syarat untuk dapat terampil berbahasa, yaitu terampil menyimak, berbicara, membaca, dan menulis. Oleh karena itu, pembelajaran kosakata dan struktur kalimat dapat diwujudkan melalui pembelajaran individu atau kelompok, pembelajaran komputer, belajar mandiri, dan penggunaan berbagai media dapat berpengaruh terhadap usaha penciptaan lingkungan kebahasaan. Pembelajaran dalam dunia pendidikan menampakkan bahwa media pembelajaran dapat menciptakan suasana belajar yang optimal.

Mencermati uraian tersebut dapat dinyatakan bahwa tidak semua siswa di sekolah dapat mencapai hasil belajar 
yang maksimal. Berbagai usaha yang diterapkan oleh pendidik dalam pembelajaran kosakata dan struktur kalimat, tetapi hasilnya masih belum memuaskan. Dalam hal penguasaan siswa terhadap kosakata dan struktur kalimat yang masih sangat sangat kurang dikarenakan pembelajaran kosakata dan struktur kalimat yang belum memuaskan. Hal tersebut dapat diketahui berdasarkan hasil penelitian di sekolah, di antaranya: (Hadinah, 2006) terkait penelitian penguasaan perbendaharaan makna kosakata siswa kelas VIII SMP Aisyiyah Sungguminasa melalui pembacaan novel yang hasil penelitiannya menunjukkan bahwa penguasaan siswa masih kurang, dan; (2) Asriani (2008) yang mengkaji tentang kemampuan penggunaan kosakata dalam menulis karangan murid kelas VI SD 21 Malelang Kecamatan Pangkep Kabupaten Pangkep dengan hasil penelitiannya menunjukkan bahwa penguasaan kosakata masih kurang.

Fenomena yang terjadi dalam konteks pembelajaran kosakata dan struktur kalimat di kelas X SMA Negeri 2 Bantaeng Kabupaten Bantaeng berdasarkan hasil observasi peneliti adalah para murid masih kesulitan dalam berbicara dan menulis yang disebabkan oleh perbendaharaan kosakatadan struktur kalimat yang kurang. Ketika muncul pertanyaan yang berkaitan dengan kosakata tertentu, siswa masih sulit menemukannya. Misalnya, kosakata yang berkaitan dengan lingkungan, maka siswa sulit menciptakan kosakatasebanyak mungkin yang berkaitan dengan lingkungan. Apabila murid ditugasi mengartikan kata tertentu maka siswa tidak memiliki konsep dan pikiran tentang arti kata tersebut.Jika siswa ditugasi mengelompokkan kata-kata berdasarkan kategori (kata sifat, kata benda, kata kerja, kata bilangan, dan kata keterangan), maka siswa sulit menyelesaikannya.

Kondisi seperti ini sangat berpengaruh terhadap keterampilan menulis siswa khususnya menulis karangan deskripsi. Masalah yang dialami siswa dalam menulis karangan deskripsi yaitu dari segi penggunaan ejaan yang meliputi penulisan huruf besar, penulisan kata depan, dan penulisan tanda baca yang belum sesuai dengan ejaan yang disempurnakan.

Sejalan yang dikemukakan oleh Tarigan (2011: 14) bahwa kualitas keterampilan berbahasa seseorang jelas bergantung kepada kualitas dan kuantitas kosakata yang dimilikinya.Semakin kaya kosakata yang kita miliki maka semakin besar pula kemungkinan kita terampil menulis.Keberhasilan siswa di sekolah pada setiap mata pelajaran ditentukan oleh perbendaharaan kosakata dan struktur kalimat yang dimilikinya.Banyak orang tidak menyadari bahwa nilai yang tertera pada buku laporan pendidikan siswa itu adalah cermin dari kualitas dan kuantitas kosakata dan struktur kalimat siswa. Baik,sedang, atau kurang nilai yang diperoleh siswa tergantung pada kosakata, struktur kalimat dan keterampilan berbahasa yang dimilikinya.

Apabila masalah ini dipahami dengan seksama, maka dapatlah dimengerti betapa pentingnya pengajaran kosakata dan struktur kalimat yang bersistem di sekolahsekolah terutama di sekolah menengah atas. Kualitas dan kuantitas kosakata dan struktur kalimat seorang siswa turut menentukan keberhasilan siswa itu sendiri.

Kurangnya penguasaan kosakatadan struktur kalimat siswa dipengaruhi oleh penggunaankosakata dan struktur kalimat dalam kehidupan sehari-hari dan dalam berkomunikasi di lingkungansekitarnya. Faktor lain yang menyebabkan kurangnya penguasaan kosakata dan struktur kalimat siswa adalah faktor yang bersifat internal maupun yang bersifat eksternal. Salah satu faktor internal adalah latar belakang pemerolehan bahasanya. Kurangnya penguasaan kosakatadan struktur kalimat siswa tersebut dipengaruhi oleh penggunaan bahasa dalam kehidupan sehari-hari. Faktor internal lain adalah pemerolehan bahasa pertamanya.Faktor eksternal adalah sistem pembelajaran yang bersifat konvensional yang menyebabkan lambangnya siswa dalam memperoleh kosakata. Sistem pembelajaran sangat menentukan keberhasilan siswa dalam memahami kosakata tertentu. 
Merujuk pada uraian di atas, guru harus mengupayakan peningkatan penguasaan kosakata siswa agar dapat: (1) meningkatkan taraf pengetahuan para siswa; (2) meningkatkan taraf kemampuan mental para siswa; (3) meningkatkan taraf perkembangan konseptual para siswa; (4) mempertajam proses berpikir kritis para siswa; (5) memperluas cakrawala pandangan hidup para siswa.

Salam (dalam Budianta, 1992: 28) mengemukakan bahwa dalam mengembangkan kosakata, seorang penulis dapat menempuh berbagai cara antara lain; (a) menyelidiki perbendaharaan kata melalui band-recorder, (b) memperhatikan perbendaharaan kata yang didapat oleh orang lain, (c) membaca buku-buku yang bermutu, guna memperoleh kosakata yang ilmiah, (d) mendengarkan pidato dan para ahli atau orang-orang terkenal, (e) melatih penggunaan kata-kata sinonim, dan (f) mempertinggi frekuensi berbicara atau menulis.

Keterampilan menulis merupakan salah satu keterampilan berbahasa yang bersifat produktif. Keterampilan menulis memiliki sifat yang sama dengan keterampilan berbicara. Keduanya merupakan keterampilan menyampaikan gagasan, perasaan, dan pengalaman kepada orang lain dengan menggunakan bahasa.

Dalam bahasa tulis, seorang penulis harus dapat mengungkapkan ide secara jelas, runtut, dan logis. Untuk itu, penulis dihadapkan pada dua masalah, yaitu menyatukan apa yang sebenarnya dimaksudkan danmembuat maknanya jelas bagi pembacanya. Dalam hal ini, dia harusmampu memilih kosakata yang tepat, menyusun dalam kalimat-kalimat yang baik, serta merangkaikannya dalam paragrafparagraf yang berkesinambungan.

Kemampuan menulis meliputi tiga aspek, yaitu aspek isi, aspek retorika, dan aspek kebahasaan.Aspek ini mencakup masalah penulisan dan pengembangan ide pokok, pengembangan kalimat utama menjadi paragraf, dan relevansi isi dengan topik. Aspek retorika membahas pengorganisasian ide termasuk di dalamnya teknik penyampaian.Aspek kebahasaan meliputi tata bahasa, diksi, ejaan, dan tanda baca.

Kemampuan menulis pada umumnya bukan merupakan kemampuan bawaan.Kemampuan ini harus dipelajari dengan baik dan dilatih secara intensif. Untuk menjadi penulis yang terampil seseorang harus menguasai hal-hal berikut ini, yaitu penguasaan terhadap isi yang akan ditulis, penguasaan teknik untuk mengorganisasikan ide dalam tulisan, penguasaan aspek kebahasaan, dan penguasaan unsur mekanik.

Menurut Keraf (2011:85), tujuan menulis untuk mengungkapkan fakta, perasaan sikap, dan isi pikiran secara jelas dan efektif, termasuk menulis paragraf. Menulis paragraf adalah pengembangan ide pokok atau kalimat utama dengan kalimatkalimat penjelas yang merupakan ide-ide penjelasan baik secara deduktif maupun induktif, secara sebabakibat atau akibat sebab (Soejito dan Hasan, 2006:24). Pengembangan tersebut dapat dilakukan dengan cara menentukan kata-kata kunci, kemudian kata-kata kunci disusun menjadi kalimat, dan kalimat-kalimat itu disusun menjadi paragraf. Paragraf merupakan suatu piranti untuk berkomunikasi secara tertulis, yakni komunikasi antara penulis dengan pembaca.Seorang penulis menyatakan gagasan/pikirannya dalam tulisan, sehingga seorang pembaca dapat mengerti ide sedikit demi sedikit hingga keseluruhan kalimat dalam paragraf (Syafi'ie, 2010:144).

Paragraf dapat dipandang sebagai karangan dalam bentuk mini yang mempunyai karakteristik sama dengan karangan lengkap (Syafi'ie, 2010: 145). Paragraf merupakan karangan yang lengkap, ketiga aspek (aspek isi, retorika, dan aspek kebahasaan) juga terdapat dalam paragraf. Namun demikian, dalam sebuah karangan paragraf tetap merupakan bagian karangan. Digambarkan karena apabila dilihat dari segi isi, isi pokok yang dikemukakan dalam suatu paragraf merupakan perincian dari isi pokok karangan.

Paragraf yang baik harus memenuhi lima persyaratan, yaitu empat syarat utama 
dan dan satu syarat bukan faktor utama. Kelima persyaratan itu adalah: (1) adanya kalimat topik, (2) adanya kalimat penunjang, (3) adanya keutuhan pikiran dalam paragraf, (4) adanya keruntutan pikiran untuk memudahkan pembaca memahamipikiran penulis, dan (5) adanya kalimat penyimpul dan ini bukan faktor utama. Kelima persyaratan tersebut harus ada dalam paragraf.Apabila salah satu syarat tidak ada dalam paragraf berarti paragraf itu tidak lengkap atau tidak baik.

Selain itu, paragraf digambarkan baik atau padu apabila hal-hal yang membentuk paragraf terjalin secara erat. Kepaduan paragraf dapat ditandai dengan berbagai cara, seperti penggunaan kalimat transisi, pengulangan kata kunci, penggunaan kata ganti, dan akan efektif apabila paragraf itu mempunyai kalimat penyimpul.

Pada hakikatnya, yang paling utama disajikan dalam pengajaran bahasa Indonesia adalah kosakata.Mungkin tidak berlebihan kalau dikatakan mempelajaribahasa berarti mempelajari kata-kata dari bahasa itu sendiri. Tanpa penguasaan kosakata yang memadai, seseorang tidak akan pernah memiliki keterampilan berbahasa yang baik. Dengan kata lain, penguasaan kosakata perlu dimiliki setiap orang untuk menguasai keterampilan berbahasa. Jadi, semakin banyak kosakata yang dikuasai seseorang, maka dapat terampil pula berbahasa dengan baik.Menurut Chauchard (dalam Mustansyir, 1991: 13) bahwa manusia setiap saat berpikir dengan mempergunakan kosakata dan pengertian. Tanpa kata-kata manusia tidak akan mungkin berpikir, bahkan volume berpikir manusia itu sebanding dengan perbendaharaan kata yang dimilikinya.

Kosakata berarti perbendaharaan kata atau kekayaan kata yang dipakai.Sebagai tolok ukur keterampilan berbahasa kosakata merupakan tolok ukur perbendaharaan kata yang dipakai, wawasan kata yang digunakan, serta ketetapan pemakaiannya dalam konteks kalimat. Keraf (2009: 80) mengatakan bahwa kosakata adalah keseluruhan kata yang berada dalam ingatan seseorang yang segera akan menimbulkan reaksi bila mendengar materi membaca.
Selanjutnya, Adwinata (dalam Martono, 1990: 5) mengaitkan kosakata sebagai berikut (1) semua kata yang terdapat dalam semua bahasa; (2) kata yang dikuasai oleh seseorang atau kata-kata yang dipakai oleh segolongan orang dalam lingkungan yang sama; (3) daftar sejumlah kata atau frasa dari sebuah bahasa yang disusun secara alfabetis disertai bahasa dan keterangannya.

Menurut Kridalaksana (1993: 127), bahwa kosakata adalah (1) komponen bahasa yang memuat semua informasi tentang makna/arti dan pemakaian kata dalam bahasa; (2) kekayaan kata yang dimiliki oleh seseorang pembicara, penulis dari suatu bahasa.Selanjutnya, Soedjito (dalam Citra, 1999: 9) mengemukakan bahwa kosakata dapat diartikan sebagai (1) semua kata yang terdapat dalam satu bahasa; (2) kekayaan kata yang dialami oleh pembicara dan penulis; (3) kata yang dipakai dalam satu bidang ilmu pengetahuan; (4) daftar kata yang disusun seperti kamus yang disertai penjelasan singkat dan praktis.

Berdasarkan pendapat di atas dapat dipahami bahwa kosakata merupakan keseluruhan kata yang dimiliki oleh suatu bahasa, baik yang diucapkan, didengar, ditulis, dan dibaca.Sementara itu, yang dimaksud dengan penguasaan kosakata dalam penelitian ini adalah kemampuan seseorang memperdalam dan menggunakan kekayaan kata ataupun istilah-istilah suatu bahasa, baik dalam menyimak, berbicara, membaca dan menulis konsep-konsep yangditentukan.

\section{METODE}

\section{Variabel Penelitian}

Penelitian ini memiliki tiga variabel, yaitu kemampuan menggunakan kosakata sebagai variabel bebas $\left(\mathrm{X}_{1}\right)$, kemampuan menggunakan struktur kalimat sebagai variabel bebas $\left(\mathrm{X}_{2}\right)$, dan kemampuan menulis paragraf deskripsi sebagai variabel terikat $(y)$.

\section{Desain Penelitian}

Jenis penelitian ini adalah penelitian korelasi atau penelitian yang ingin mengetahui pengaruh antara tiga variable. Oleh karena 
itu, untuk memperoleh data yang akurat sesuai dengan masalah penelitian ini dirancang secara deskriptif- kuantitatif dengan desain atau model penelitian yang digunakan dalam penelitian ini, yaitu desain penelitian korelasi.

\section{Populasi}

Populasi penelitian ini adalah seluruh siswa kelas X SMA Negeri 2 Bantaeng Kabupaten Bantaeng yang berjumlah 185 orang yang terdiri atas 5 (lima) kelas. Rincian jumlah tersebut dapat dilihat pada tabel berikut.

Tabel 1: Keadaan populasi

\begin{tabular}{|c|c|c|c|c|}
\hline \multirow{2}{*}{ No } & \multirow[b]{2}{*}{ Kelas } & \multicolumn{2}{|c|}{ Jenis kelamin } & \multirow{2}{*}{ Jumlah } \\
\hline & & Laki-laki & Perempuan & \\
\hline 1. & X.I & 16 & 21 & 37 \\
\hline 2. & X.II & 13 & 24 & 37 \\
\hline 3. & X.III & 17 & 20 & 37 \\
\hline 4. & X.IV & 17 & 20 & 37 \\
\hline 5. & X.V & 18 & 19 & 37 \\
\hline Total & & 81 & 104 & 185 \\
\hline
\end{tabular}

Sumber : Dokumentasi SMA Negeri 2 Bantaeng Kabupaten Bantaeng

\section{Sampel}

Sampel ditetapkan menjadi wakil populasi yang diteliti.Tujuan dari penentuan sampel adalah untuk memperoleh keterangan mengenai obyek yang diteliti dengan cara mengamati hanya sebagian dari populasi. Tujuan lain dari sampel adalah untuk mengetahui sifat-sifat umum dari populasi untuk menarik generalisasi dari hasil penyelidikan, mempermudah penafsiran, peramalan dan pengujian hipotesis. Pada penelitian ini penarikan sampel ditentukan dengan menggunakan teknik random sampling dengan cara undian yang keluar sebagai sampel adalah kelas X.I sebanyak 37 orang.

\section{Teknik Pengumpulan dan Analisis Data}

Data dalam penelitian ini diperoleh melalui teknik tes, tes adalah serentetan pertanyaan atau latihan serta alat lain yang digunakan untuk mengukur keterampilan, pengetahuan, intelegensi kemampuan atau bakat yang dimiliki oleh individu atau kelompok (Arikunto, 2006: 150). Bentuk tes yang disajikan adalah memberikan tes kosakata dalam bentuk tes pilihan ganda. Data yang diperoleh dianalisis dengan menggunakan analisis regresi linear berganda.

\section{HASIL DAN PEMBAHASAN}

Mengacu pada hasil analisis data dapat diketahui bahwa nilai rata-rata $\mathrm{Y}=38,92$ dengan standar deviasi $(\mathrm{SD})=3,93$ nilai ratarata $\mathrm{X}_{1}=38,27$ dengan standar deviasi (SD) $=3,79$ dan nilai rata -rata $\mathrm{X}_{2}=37,86$ dengan standar deviasi $(\mathrm{SD})=3,91$. Berdasarkan hasil tersebut dapat diketahui bahwa responden (siswa) yang memperoleh skor di bawah rata-rata pada variable $Y$ (kemampuan menulis paragraf deskripsi) Sebanyak 6 orang atau $16,22 \%$ dan yang memperoleh nilai diatas rata-rata sebanyak 31 orang 83,78\%. Untuk variabel $\mathrm{X}_{1}$ (pegguna kosakata) responden yang memperoleh nilai di bawah sekor rata-rata sebanyak 8 orang atau $21,62 \%$ dan yang memperoleh niali di atas Rata-rata sebanyak 29 orang atau 78,38\% Sedangkan untuk variabel $\mathrm{X}_{2}$ (struktur kalimat) responden yang memperoleh nilai di atas rata-rata sebanyak 22 orang atau $59,46 \%$. Secara parsial semua variabel bebas mempunyai pengaruh yang signifikan hal ini bisa dilihat dari nilai $\mathrm{t}$ hitung maupun Sig, dimana nilai t hitung lebih besar dari t tabel sedangkan nilai Sig masih dibawah Alpha 0,05 .

Variabel kemampuan menggunakan kosakata pengaruhnya signifikan terhadap kemampuan menulis paragraf deskripsi ( $\mathrm{t}$ hitung $=3.605>\mathrm{t}$ tabe $!=2,021)$. Demikian juga nilai Sig $=0.001<0,05$ dengan koefisien regresi sebesar 0.633 . Hal ini menyimpulkan bahwa hipotesis diterima. Demikian juga 
dengan variabel kemampuan menggunakan struktur kalimat, dengan melihat nilai yang sama seperti di atas dapat disimpulkan bahwa, menggunakan struktur kalimat mempunyai pengaruh signifikan terhadap kemampuan menulis paragraf deskripsi. Hal ini menyimpulkan baliwa hipotesis diterima.

Dari kedua variabel tersebut, dapat diperoleh informasi bahwa variabel kemampuan menggunakan kosakata mempunyai pengaruh yang paling dominan, hal ini ditunjukkan oleh nilai $\mathrm{B}$ maupun nilai beta dan $t$ yang lebih besar dan Sigma yang lebih kecil dibandingkan dengan variabel kemampuan menggunakan struktur kalimat. Berikut disajikan hasil analisisnya

\section{Kemampuan menggunakan kosa kata dan sturuktur kalimat}

Penguasaan kosa kata dan struktur kalimat merupakan dua kiomponen yang saling berkaitan terus di belajarkan. Dengan pengusaan kosa kata yang baik seseorang akan memiliki wawasan dan pengetahuan kosakata yang luas sehingga diharapkan dapat menyusun kalimat secara lebih baik. Pada penelitian ini, untuk memperoleh kemampuan menggunakan kosakata dan struktur kalimat siswa kelas X SMA Negeri 2 Bantaeng Kabupaten Bantaeng peneliti meminta siswa menuliskan beberapa kosakata kemudian menyusun kedalam beberapa kalimat.

Dari hasil deskripsi data diketahui bahwa siswa yang memperoleh skor dibawah rata-rata untuk variabel $\mathrm{X}_{1}$ (penguasaan kosakata) sebanyak 8 orang atau $21,62 \%$ dan variabel $\mathrm{X}_{2}$ (struktur kalimat) sebanyak 5 orang atau 13,51\%. Sedangkan siswa yang memperoleh skor diatas rata-rata pada variabel $\mathrm{X}_{1}$ (penguasaan kosakata) sebanyak 29 orang atau 78,38\% dan variabel $\mathrm{X}_{2}$ (struktur kalimat) sebanyak 22 orang atau 59,56\%. Dengan demikian maka dapat disimpulkan bahwa kemampuan penguasaan kosakata merupakan bagian penting dalam menyusun kalimat.Hal tersebut sesuai dengan pendapat Akhadiah (1994:40) yang menyatakan bahwa kalimat yang baik harus disusun berdasarkan kaidah-kaidah yang berlaku. Kaidah yang berlaku tersebut meliputi (a) unsur-unsur penting yang dimiliki setiap kalimat, (b) cara memilih kata dalam kalimat, dan (c) penerapan aturanaturan tentang ejaan sebagaimana dinayatakan Sugihastuti (2007:81)bahwa penentuan pilihan kata termasuk sebagai kemapuan penguasaan kosakata dijabarkan sebagai kemahiran penyusunan kelimat efektif dan ketepatan untuk menuliskannya kedalam bentuk paragraf yang baik.

Penguasaan kosakata pada individu dimulai dari pengenalan bahasa ibu melalui proses pembudayaan alami. Dengan berkembangnya usia, kemudian kosakata diperoleh pada pendidikan formal melalui proses pengajaran dan pembelajaran. Dengan penguasaan kosakata, seseorang dapat berkomunikasi dengan orang lain secara lisan maupun tulis tanpa mengalami hambatan

Berdasarkan pendapat di atas, maka disimpujkan bahwa penguasaan kosakata juga sangat berpengaruh terhadap kemampuan menulis paragraf deskripsi.Hal ini dapat dilihat pada kenyataan di lapangan bahwa banyak siswa yang gagal menulis karena penguasaan kosakata yang rendah.Beberapa penelitian juga menunjukkan bahwa kegagalan siswa dalam menulis disebabkan oleh penggunaan grammar yang tidak tepat.

Begitu banyak penelitian dilakukan untuk mencari di mana kelemahan dan apa inti persoalan sehingga mahasiswa begitu banyak yang gagal menyelesaikan karya tulis dan gagal dalam menempuh mata kuliah menulis. Hasil penelitian menunjukkan bahwa ketidakberhasilan mahasiswa banyak disebabkan oleh ketidakmampuan mahasiswa dalam memilih kata yang tepat. Di samping itu, mahasiswa juga salah memilih kosakata dengan ejaan yang tidak tepat.

Hasil penelitian itu juga berkorelasi dengan penelitian-penelitian yang 
dilakukan pada sekolah menengah. Banyak siswa yang kurang berminat dan kurang serius dalam mengikuti pembelajaran menulis. Mereka merasa kesulitan dalam menuangkan ide atau gagasan ke dalam tulisan, baik dalam bentuk puisi, prosa (cerpen), maupun drama.

Kualitas keterampilan berbahasa seseorang sangat dipengaruhi pada kualitas dan kuantitas kosakata yang dimilikinya (Tarigan 1994: 2).Semakin kaya kosakata yang dimiliki, semakin terampil pula dalam berbahasa. Perkembangan kosakata merupakan perkembangan konseptual. Suatu program yang sistematis dalam perkembangan kosakata dipengaruhi oleh usia, jenis kelamin, pendapatan, kemampuan, bawaan, dan status sosial serta faktor-faktor geografis.

Pembelajaran kosakata diajarkan dalam konteks wacana, dipadukan dengan kegiatan pembelajaran seperti percakapan, membaca, menulis.Upaya memperkaya kosakata perlu dilakukan secara terus menerus melalui surat kabar, majalah, pidato-pidato, dan sebagainya. Untuk dapat memperoleh hasil pembelajaran kosakata yang optimal, guru perlu membekali siswa dengan kata-kata yang berkaitan dengan bidang tertentu. Dalam setiap bidang iimu digunakan kata-kata khusus.Upaya pemerkayaan kosakata perlu dilakukan.

Untuk meningkatkan penguasaan kosakata dalam pembelajaran menulis paragraf deskripsi juga dapatdilakukan dengan mengembangkan bahan ajar. Bahan ajar harus berkaitan dengan materikosakata.

Di masa lampau, pengajaran dan pelajaran kosakata sering diberikan sedikit prioritas dalam program bahasa kedua, tapi akhir-akhir ini sudah ada kepentingan baru dalam hal kosakata dan peranannya dalam pelajaran dan pengajaran. Secara tradisional, pelajaran kosakata sering dibiarkan untuk dipelajari secara mandiri dan hanya menerima sedikit perhatian dalam banyak buku teks dan program bahasa.Namun demikian, meskipun tujuan kurikulum seringkali cukup spesifik mengenai aspek pengajaran seperti tatabahasa, membaca, atau berbicara, sedikit perincian diberikan untuk peranan kosakata.Status kosakata sekarang sepertinya berubah. Untuk satu hal, gagasan mengenai sebuah kata telah "diperluas" mencakup firasa leksikal dan kebiasaan sehari-hari, dan teiah disarankan bahwa tahapan awal mempelajarinya memainkan peranan penting dalam komunikasi dan kemahiran.

Lebih lanjut, akses terhadap korpora leksikal telah memungkinkan linguistik terapan untuk mengidentifikasi pola umum kolokasi, pembentukan kata, metaphor, dan frasa leksikal yang merupakan bagian dari kecakapan leksikal pembicara.

\section{Kemampuan menulis paragraf deskripsi}

Kemampuan menulis paragraf deskripsi siswa kelas X SMA Negeri 2 Bantaeng Kabupaten Bantaeng dalam penelitian ini yaitu rata-rata 38,92 siswa yang memperoleh skor dibawah rata-rata sebanyak 6 orang atau $16,22 \%$ dan siswa yang memperoleh skor diatas rata-rata sebanyak 31 orang atau 83,78\%.

Kemampuan menulis paragraf deskripsi siswa diperoleh dari hasil tes menulis penguasaan paragraf deskripsi setelah diajar dengan kosakata dan struktur kalimat.Hasil penelitian yang diperoleh yaitu siswa sudah banyak yang mampu menulis paragraf deskripsi dengan baik. Hasil penelitian tersebut sejalan dengan pendapat Tarigan (1994:4-5) yang menyatakan bahwa kegiatan menulis tidak dapat dipisahkan dengan kegiatan menyusun kalimat. Keterampilan menulis merupakan keterampilan yang sangat penting dalam kehidupan tidak hanya penting dalam kehidupan pendidikan tetapi juga sangat penting dalam kehidupan masyarakat. Keterampilan menulis itu sangat penting 
karena merupakan salah satu keterampilan berbahasa yang harus dimiliki oleh siswa.

3. Pengaruh antara kemampuan menggunakan kosakata dan struktur kalimat terhadap kemampuan menulis paragraf deskripsi

berdasarkan hasil pengujian hipotesis diperoleh nilai $\mathrm{R}=0,9$ dan nilai $\mathrm{F}$ hitung sebesar 314,542 sedangkan nilai $\mathrm{F}$ tabel sebesar 3,28 maka dapat disimpulkan bahwa ada pengaruh antara kemampuan menggunakan kosakata dan struktur kalimat terhadap kemampuan menulis paragraf deskripsi siswa kelas X SMA Negeri 2 Bantaeng Kabupaten Bantaeng. Dengan demikian maka hipotesis alternatif $\left(\mathrm{H}_{1)}\right.$ yang berbunyi " terdapat pengaruh kemampuan menggunakan kosakata dan struktur kalimat terhadap kemampuan menulis paragraf deskripsi siswa kelas X SMA Negeri 2 Bantaeng Kabupaten Bantaeng" dinyatakan diterima sedangkan hipotesis nihil $\left(\mathrm{H}_{0}\right)$ yang berbunyi, tidak ada pengaruh kemampuan menggunakan kosakata dan struktur kalimat terhadap kemampuan menulis paragraf deskripsi siswa kelas $\mathrm{X}$ SMA Negeri 2 Bantaeng Kabupaten Bantaeng, dinyatakan ditolak. Dalam hal ini kemampuan menggunakan kosakata dan struktur kalimat mempunyai pengaruh positif terhadap kemampuan menulis paragraf deskripsi siswa kelas $\mathrm{X}$ SMA Negeri 2 Bantaeng Kabupaten Bantaeng, artinya semakin tinggi kemampuan menulis paragraf deskripsi siswa. Siswa dikatakan siap belajar menulis jika mampu mengingat urutan huruf dan tahu perbedaan, dapat memusatkan ide dan gagasan, serta kembali ke baris berikutnya, mempunyai bahasa tulis yang benar yang berisi kosakata selain pandangan dan percakapan, serta susunan kalimat normal, dan mudah menangkap pengertian - pengertian yang diperkenalkan.

\section{SIMPULAN}

Mengacu pada hasil analisis dan pembahasan terhadap masalah-masalah penelitian dan hipotesis yang telah dibahas pada bab-bab terdahulu, maka hasilnya dapat disimpulkan bahwa: (1) Kosakata memegang fungsi dan peranan yang sangat penting dalam keterampilan berbahasa. Kosakata dapat menambah ilmu bahasa seseorang sehingga pengetahuan yang dimiliki semakin luas.Dalam penelitian ini Kemampuan menggunakan kosakata siswa kelas X SMA Negeri 2 Bantaeng Kabupaten Bantaeng nilai rata-ratanya -= 38,27 dengan standar deviasi 3,79; (2) Kalimat adalah satuan bahasa terkecil, dalam wujud lisan atau tulisan yang mengungkapkan pikiran yang utuh.Kemampuan menggunakan srtuktur kalimat siswa kelas X SMA Negeri 2 Bantaeng Kabupaten Bantaeng nilai rataratanya $=38,92$ dengan standar deviasi= 3,93; (3) Terdapat pengaruh secara bersama-sama antara kemampuan menggunakan kosakata dan struktur kalimat terhadap ke mampuan menulis paragraf deskripsi siswa kelas X SMA Negeri 2 Bantaeng Kabupaten Bantaeng. Hal ini disebabkan nilai $\mathrm{F}$ hitung yang diproleh lebih besar yaitu 314,542 dari pada nilai $F$ tabel yaitu 3,28 atas dasar taraf signifiakasi $5 \%$ dan secara parsial semua variabel bebas mempunyai pengaruh yang signifikan, hal ini disebabkan nilai $\mathrm{T}$ hitung yang diperoleh yaitu 3,605 lebih besar dari nilai T-tabel yaitu 2,021.

\section{DAFTAR RUJUKAN}

Akhadiah, S. (1994). Pembinaan Kemampuan Menulis, Jakarta: Erlangga.

Arikunto, S. (2006). Prosedur Penelitian Kualitatif dan Kuantitatif. Jakarta: Rineka Cipta

Asriani. (2008). Kemampuan menggunakan kosakata dalam menulis karangan deskripsi murid kelas VI SDN 21 Malelang Kecamatan Pangkep Kabupaten Pangkep. Laporan penelitian: Tidak dipublikasikan. 
Budianta, E. (1992). Menggebrak Dunia Mengarang. Jakarta: Pustaka Pembangunan Swadaya Nusantara.

Citra.(1999).Penguasaan Kosakata Bahasa Indonesia Kelas III Batara Gowa Singguminasa. Skripsi. Ujung Pandang: FPBS IKIP Ujung Pandang.

Hadinah. (2006).Penguasaan Perbendaharaan Kosakata Siswa Kelas VIII SMP AisyiyahSimgguminasa, Kabupaten Gowa melalui Bacaan Novel. Skripsi. Makassar: Fakultas Bahasa dan Sen! Universitas Negeri Makassar.

Halim, A. (2005). Politik Babasa Nasional. Jakarta: Pusat Pembinaan dan Pengembangan Bahasa.

Keraf, G. (2009).Tata Bahasa Indonesia.Ende: Nusa Indah.

Keraf, G. (2011). Diksi dan Gaya Bahasa.Jakarta: Gramedia Pustaka Utama.

Kridalaksana, H. (1993). Kamus Linguistik. Jakarta: Gramedia Pustaka Utama.

Martono. (1990). Kosakata Bahasa TulangMamak. Jakarta. Depdibud
Mustansyir, R. (1991). Filsafat Bahasa. Aneka Masalab Arti dan Upaya Pemecahannya. Jakarta: Prima Karta.

Soedjito, \& Hasan, M. (2006). Keterampilan Menulis Paragraf. Bandung: Remaja Rosdakarya.

Sugihastuti.(2007).Tata Bahasa Baku Bahasa Indonesia. Jakarta : Bulan Bintang

Syafi'ie, I. (2010). Retorika dalam Menulis. Jakarta Dekdikbud: P2LPTK.

Tarigan, H.G. (1994)..Prinsip-prinsip Dasar Sastra. Bandung: Angkasa

Tangan, H.G.(2011).Pengajaran Kosakata. Bandung: Angkasa.

\section{UCAPAN TERIMA KASIH}

Peneliti mengucapkan terima kasih kepada pihak-pihak yang telah membantu pelaksanaan penelitian ini di antaranya kepada pihak sivitas akademika SMA Negeri 2 Bantaeng Kabupaten Bantaeng atas bantuannya dalam hal penyediaan lokasi penelitian, dan siswa kelas $\mathrm{X}$ yang telah menjadi responden penelitian ini. 